\title{
A High Antibacterial Efficacy of Fruits of Litsea cubeba (Lour.) Pers from Nepal. GC-MS and Antioxidative Capacity Analyses
}

\author{
Gan B Bajracharya ${ }^{1, *}$, Pratigya KC ${ }^{2}$
}

\section{Gan B Bajracharya ${ }^{1, *}$, Pratigya \\ $\mathrm{KC}^{2}$}

'Faculty of Science, Nepal Academy of Science and Technology (NAST), Khumaltar, Lalitpur, NEPAL.

${ }^{2}$ Department of Chemistry, Tri-Chandra

Multiple Campus, Tribhuvan University,

Kathmandu, NEPAL.

\section{Correspondence}

\section{Gan B. Bajracharya}

Senior Scientific Officer, Faculty of Science, Nepal Academy of Science and Technology (NAST), Khumaltar, Lalitpur, NEPAL.

Phone no: +977 1 5547368; +977 9849636069;

E-mail: gan.bajracharya@nast.gov.np: ganbajracharya@yahoo.com

History

- Submission Date: 22-01-2019;

- Review completed: 18-03-2019;

- Accepted Date: 24-04-2019.

DOI : 10.5530/pj.2019.11.142

Article Available online http://www.phcogj.com/v11/i5

\section{Copyright}

(c) 2019 Phcogj.Com. This is an openaccess article distributed under the terms of the Creative Commons Attribution 4.0 International license.

\begin{abstract}
Background: Biological activities of the plant materials may vary with different geographic origin. Litsea cubeba fruits are consumed in Nepal as a spice ingredient and are considered to be possessed antibacterial property. Objectives: Aims of this work are: to compare phytoconstituents present in litsea oil by GC-MS analysis, and to evaluate antibacterial and antioxidant activities of the volatile oil and the fruit extracts. Materials and Methods: Hydrodistillation of $L$. cubeba fruits was performed to obtain litsea oil followed by extractions with boiling methanol. Fractionations of the extract provided hexane, dichloromethane, ethyl acetate and aqueous extracts. The oil and extracts were analysed for the phytochemicals present. They were evaluated by using antibacterial susceptibility, brine-shrimp lethality and antioxidant capacity assays. Results: All together 49 compounds (accounting 93.66\%) were identified in the litsea oil by GC-MS. Monoterpenes being dominant components, the oil constituted $15.96 \%$ of citral (geranial and neral). Other major constituents were capric acid $(12.44 \%)$, $\beta$-caryophyllene oxide (7.69\%), linalool (5.96\%), eucalyptol $(5.13 \%)$ and cis$\beta$-terpineol (4.22\%). Litsea oil, hexane extract and dichloromethane extract displayed very effective antibacterial property. Ethyl acetate extract $\left(\mathrm{LC}_{50}=21.52 \mu \mathrm{g} \mathrm{mL}^{-1}\right)$ and litsea oil ( $\mathrm{LC}_{50}$ $\left.=31.62 \mu \mathrm{g} \mathrm{mL}^{-1}\right)$ were found highly cytotoxic against brine-shrimp nauplii. Ethyl acetate $\left(\mathrm{IC}_{50}\right.$ $\left.=124.57 \mu \mathrm{g} \mathrm{mL}^{-1}\right)$ and dichloromethane $\left(\mathrm{IC}_{50}=271.08 \mu \mathrm{g} \mathrm{mL}^{-1}\right)$ extracts displayed a modest DPPH free radical scavenging activity. Conclusion: Phytoconstituents present in the L. cubeba fruits from Nepal were analysed. Litsea oil and the extracts have displayed high antibacterial and potentially anticarcinogenic activities.
\end{abstract}

Key words: Antioxidant, Brine-shrimp assay, DPPH assay, GC-MS analysis, Litsea oil, Minimum bactericidal concentration.

\section{INTRODUCTION}

Litsea cubeba (Lour.) Pers (Nepali name: siltimur, family: Lauraceae) is native to East Asia and distributed in East and Central Nepal at 1000-2700 meters altitude. ${ }^{1}$ It is a perennial, dioecious tree or shrub, 5-12 meters high, lemongrass scented arils and pepper shaped fruits. It contains amides, alkaloids, steroids, terpenoids, fatty acids and lignans. ${ }^{2}$

Hydrodistillation of $L$. cubeba fruits produces litsea oil, which has lemon like spicy odour and used for manufacturing of citral, vitamins A, E and $\mathrm{K}$, ionone, methylionone and perfumes. ${ }^{3-5}$ Its antibacterial, ${ }^{6,7}$ antifungal, ${ }^{8}$ antioxidant, ${ }^{9}$ mosquito repellent ${ }^{10}$ and anticancer ${ }^{11}$ properties are recently reported.

The composition of L. cubeba oil has been reviewed in a few literatures. ${ }^{12,13}$ Literature search revealed that the chemical composition of litsea oil varies with different geographic areas and thereby the synergistic or antagonistic effects cause different biological activities. ${ }^{714-17}$ Several authors have reported that citral ( $\alpha$-citral; geranial and $\beta$-citral; neral) is the major constituent in the oil.7,11,18-21 In Indian litsea oil, Gogoi et al. have reported that citral (geranial $51.9 \%$ and neral $40.7 \%$ ) was the major constituent. ${ }^{18}$ On the other hand, citronellal (44.8-77.2\%) and citronellol (10.9-14.0\%) were the major constituents but not citral (geranial 0.2$0.4 \%$ ) in litsea oil from Assam, India. ${ }^{22}$ Litsea oil of Chinese variety contained nerol, $\beta$-caryophyllene, 2,6-dimethyl-5-heptenal and 6-methyl-5-hepten-2ol as major constituents. ${ }^{22}$ On the other hand, the major constituents of Tibetian, Chinese litsea oil were limonol $(44.2 \%)$, linalool $(8.8 \%)$, eucalyptol (5.4\%), elemicin (3.9\%), methyl euginol (3.8\%), etc. $^{8}$ In litsea oil from Jiangxi province of China, $\mathrm{Si}$ et al. ${ }^{15}$ have reported that citral (80.6-82.9\%) and limonene (4.1-5.3\%) were the major constituents, while the composition was varied with citral (47.9\%) and limonene $(26.2 \%)$ in a report of Wang et al. ${ }^{23}$ The ethanolic extract of $L$. cubeba fruits from Zhejiang Province, China was analysed by $\mathrm{Hu}$ et al., and thirty compounds were identified with citral (59.3\%) and limonene $(8.5 \%)$ as the predominant compounds. ${ }^{14}$ Therefore, the composition of litsea oil remarkably varied within India and China. Since Nepal lies between these two countries, we decided to compare the variation in the oil composition from our own product to the global distribution and its affects in the bioactivities. Herein, we report the identification and quantification of volatiles of litsea oil by GCMS, phytochemical screening of the fruit extracts, and in vitro evaluation of antibacterial activity and antioxidant capacity of the oil and extracts.

Cite this article: Bajracharya GB, Pratigya KC. A High Antibacterial Efficacy of Fruits of Litsea cubeba (Lour.) Pers from Nepal. GC-MS and Antioxidative Capacity Analyses. Pharmacog J. 2019;11(5):889-93. 


\section{MATERIALS AND METHODS}

\section{Plant material}

Fresh fruits of L. cubeba (Lour.) Pers were collected from Shantipur, Gulmi District, Western Nepal (altitude 1300 meters, latitude $28^{\circ} 6^{\prime} \mathrm{N}$ and longitude $83^{\circ} 24^{\prime} \mathrm{E}$ ) in June 2012 . The plant species was authenticated from National Herbarium and Plant Research Lab, Godawori, Lalitpur, Nepal with a Voucher Specimen Number 19-070/071.

\section{Extraction of the plant material}

Hydrodistillation of the dried and coarsely ground fruit sample (500 g) using a Clevenger apparatus (oil lighter than water type) for $4.5 \mathrm{~h}$ afforded litsea oil $(7 \mathrm{~mL}, 1.40 \% \mathrm{v} / \mathrm{w})$, which was dried over anhydrous $\mathrm{Na}_{2} \mathrm{SO}_{4}$ and stored at $4^{\circ} \mathrm{C}$ until analysis. The marc remained was extracted with boiling methanol $(800 \mathrm{~mL} \times 5 \mathrm{~h} \times 3$ times $)$. The combined alcoholic extract was concentrated, diluted with water and then subsequently fractionated with hexane $(500 \mathrm{~mL} \times 4)$, dichloromethane $(500 \mathrm{~mL} \times$ 4) and ethyl acetate $(500 \mathrm{~mL} \times 4)$ followed by concentrations to obtain corresponding hexane, dichloromethane, ethyl acetate and aqueous extracts.

\section{Phytochemical screening}

The fruit extracts were subjected to different qualitative tests to identify the presence of various phytochemical constituents. ${ }^{24,25}$ Following tests were conducted: Dragendorff's test for alkaloids, LiebermannBurchard's test for sterols and triterpenes, Shinoda's test for flavonoids, Borntiager's test for anthraquinones, Kedde's test for cardiac glycosides, Molisch's test for polyoses, ferric chloride test for tannins and polyphenols, dinitrobenzoic acid test for lactones, fluorescence test for coumarins, spot test for fatty acids, froth test for saponins, acid test for carotenoids, and base tests for anthocyanosides and anthracenosides.

\section{Gas chromatography-mass spectrometry analysis}

Chemical constituent of litsea oil was analysed by GC-MS using an Agilent 7890A GC system coupled with an Agilent 5975 C mass selective detector. The GC column was HP-5MS (5\% phenyl methyl siloxane, Agilent 19091S-433, $30 \mathrm{~m} \times 250 \mu \mathrm{m}$ internal diameter, $0.25 \mu \mathrm{m}$ film thickness). Helium was used as a carrier gas at flow rate of $1 \mathrm{~mL} \mathrm{~min}$. A $5 \% \mathrm{v} / \mathrm{v}$ sample solution was prepared in methanol and a volume of 0.5 $\mu \mathrm{L}$ was injected using a split mode. The initial column temperature was set at $50^{\circ} \mathrm{C}$ held for $2 \mathrm{~min}$, ramped at a rate of $3^{\circ} \mathrm{C} \mathrm{min}^{-1}$ to $120^{\circ} \mathrm{C}$ and held for $2 \mathrm{~min}$, and then increased to $250^{\circ} \mathrm{C}$ at rate of $15^{\circ} \mathrm{C} \mathrm{min}{ }^{-1}$ (total run time $41 \mathrm{~min}$ ). The instrument was operated in the electron impact (EI) mode at $70 \mathrm{eV}$ and ion source temperature $230^{\circ} \mathrm{C}$ in the scan range of 50-1000 amu. Volatile constituents were identified by comparing the mass spectra available in a MS database (NIST 08). The identification was also made by comparing relative retention indices (RI) with the literature. ${ }^{14-15,22}$

\section{Antibacterial susceptibility assay}

The litsea oil and fruit extracts were screened for antibacterial activity against Bacillus subtilis, Staphylococcus aureus (ATCC 25923), Enterobacter cloacae, Escherichia coli (ATCC 25922), Klebsiella pneumonia (ATCC 13883), Pseudomonas aeruginosa (ATCC 27853), Salmonella typhimurium (ATCC 14038) and Serratia marcescens using the agar well diffusion assay. ${ }^{26}$ Briefly, $50 \mu \mathrm{L}$ of the sample solution in dimethyl sulphoxide (concentration of $50 \mathrm{mg} \mathrm{mL}^{-1}$ ) was dispensed into the well $(6 \mathrm{~mm})$ bored in bacteria stained Mueller Hinton agar plates. Gentamycin (10 $\mu \mathrm{g}$ disc) was used as a positive control. ZOI produced were measured after incubation at $37^{\circ} \mathrm{C}$ for $24 \mathrm{~h}$.

Microbroth dilution methodology was used to determine $\mathrm{MBC}$ values. ${ }^{27}$ Briefly, the mixture of nutrient broth agar $(1 \mathrm{~mL})$ and $1 \mathrm{~mL}$ of the sample solution in dimethyl sulphoxide (concentration of $50 \mathrm{mg}$ $\mathrm{mL}^{-1}$ ) was serially diluted and then inoculated with bacterial strains $(50 \mu \mathrm{L})$. After incubation at $37^{\circ} \mathrm{C}$ for $24 \mathrm{~h}$, a loopful of each bacterial solution was sub-cultured by streaking in nutrient agar plate. After incubation at $37^{\circ} \mathrm{C}$ for $24 \mathrm{~h}$, the $\mathrm{MBC}$ values were determined.

\section{Brine-shrimp lethality assay}

The brine-shrimp assay was used to evaluate cytotoxicity. ${ }^{28}$ Briefly, freshly hatched ten brine-shrimp (Artemia salina, procured from San Francisco Bay Brand Inc., USA) nauplii in triplicates were exposed to the sample in 10,100 and $1,000 \mu \mathrm{g} \mathrm{mL}^{-1}$ dose levels in artificial sea water (total volume $5 \mathrm{~mL}$ ) under warmth. After $24 \mathrm{~h}$, the number of survivors was counted. The percentage death and $\mathrm{LC}_{50}$ values were computed.

\section{2,2-Diphenyl-1-picrylhydrazyl (DPPH) assay}

The DPPH assay was used to evaluate antioxidant capacity. ${ }^{29}$ Briefly, overnight stirring of $3.9 \mathrm{mg}$ of DPPH (Sigma-Aldrich) in methanol $(100 \mathrm{~mL})$ at $0^{\circ} \mathrm{C}$ gave $\mathrm{DPPH}$ free radical $\left(\mathrm{DPPH}^{\bullet}\right)$ solution. Working solutions of litsea oil and fruit extracts were prepared in methanol (concentrations 5, 50, 100, 250 and $500 \mu \mathrm{g} \mathrm{mL}^{-1}$ ). Distilled water was used as a solvent to prepare working solutions of the aqueous extract. To $0.5 \mathrm{~mL}$ of the working solution was added $2.5 \mathrm{~mL}$ of DPPH ${ }^{\bullet}$ solution. A control was prepared by mixing methanol or distilled water $(0.5 \mathrm{~mL})$ and $\mathrm{DPPH}^{\bullet}$ solution $(2.5 \mathrm{~mL})$. These solutions were vortexed, kept at room temperature in the dark for $30 \mathrm{~min}$ and then absorbance was measured at $517 \mathrm{~nm}$ using a $6715 \mathrm{UV} / \mathrm{Vis}$ Spectrophotometer JENWAY. The inhibition percentage was calculated as:

Scavenging activity $(\%$ of inhibition $)=(1-$ Asample/Acontrol $) \times 100$ (1)

where, Asample and Acontrol are the absorbance values of the reaction mixture with and without sample, respectively. $\mathrm{IC}_{50}$ values were calculated. A standard linear curve was constructed using methanolic solutions of gallic acid with known concentrations of 5, 25, 50 and $75 \mu \mathrm{g}$ $\mathrm{mL}^{-1}$. The DPPH value obtained was considered the slope of the linear curve derived from the constructed graph and expressed in gallic acid equivalence (GAE).

\section{RESULTS}

\section{Extraction}

Litsea oil was obtained in $1.4 \% \mathrm{v} / \mathrm{w}$ yield by hydrodistillation of the dried fruits of $L$. cubeba as yellow oil. Subsequently, the marc was extracted with boiling methanol, concentrated and then diluted with water. Fractionation using hexane, dichloromethane and ethyl acetate followed by concentration afforded hexane extract (19.60 g, 3.92\%), dichloromethane extract $(2.76 \mathrm{~g}, 0.55 \%)$, ethyl acetate extract ( $1.63 \mathrm{~g}$, $0.33 \%)$ and aqueous extract (58.61 g, 11.72\%).

\section{Phytochemical analysis}

Although the chemical tests were essentially qualitative, phytochemical screening of the extracts of $L$. cubeba fruits revealed the presence of alkaloids, steroids, terpenoids, polyoses, polyphenols, coumarins, fatty acids, saponins and carotenoids.

GC-MS analysis of litsea oil led to identify 49 compounds accounting 93.66\% of the oil and the data are presented in Table 1.

\section{Biological assays}

The results of antibacterial susceptibility assay of litsea oil along with four different extracts against a total of eight Gram-positive and Gramnegative bacteria are depicted in Table 2 . The results of the brine-shrimp and DPPH assays are summarized in Table 3. 
Table 1: Chemical composition of litsea oil of $L$. cubeba fruits.

\begin{tabular}{|c|c|c|c|c|c|}
\hline $\mathbf{R I}^{\mathrm{a}}$ & Compound & $\%$ & $\mathbf{R I}^{\mathrm{a}}$ & Compound & $\%$ \\
\hline 3.286 & \multirow{2}{*}{$\begin{array}{l}\text { 3-methyl-2-butenal; prenal } \\
\alpha^{\text {-thujene }}\end{array}$} & 0.08 & 16.639 & borneol & 0.12 \\
\hline 6.790 & & 0.30 & 17.207 & \multirow{2}{*}{$\begin{array}{l}\text { 4-methyl-1-(1-methylethyl)-3- } \\
\text { cyclohexen-1-ol; terpinen-4-ol }\end{array}$} & \multirow[t]{2}{*}{2.06} \\
\hline 6.948 & $\alpha^{\text {-pinene }}$ & 0.97 & & & \\
\hline 7.443 & camphene & 0.07 & 17.459 & \multirow{2}{*}{$\begin{array}{l}\text { 1-(2-methylphenyl)-ethanone } \\
\alpha^{\text {-terpineol }}\end{array}$} & 0.29 \\
\hline 8.474 & $\beta^{\text {-pinene }}$ & 3.66 & 17.828 & & 0.99 \\
\hline 9.158 & 6-methyl-5-hepten-2-one; sulcatone & 4.59 & 18.007 & \multirow{2}{*}{$\begin{array}{l}\text { dihydronopol } \\
\text { neral ( } \beta^{\text {-citral })}\end{array}$} & 0.66 \\
\hline 9.326 & 6-methyl-5-hepten-2-ol; sulcatol & 0.13 & 20.395 & & 7.23 \\
\hline 10.115 & $(+)$-4-carene & 0.13 & 20.479 & \multirow{2}{*}{$\begin{array}{l}\text { 1-methyl-2-acetyl-3-(1-methylethenyl)- } \\
\text { cyclopentane }\end{array}$} & \multirow{2}{*}{1.24} \\
\hline 10.431 & $p$-cymene & 3.55 & & & \\
\hline 10.550 & $o$-cymene & 1.24 & \multirow[t]{2}{*}{20.721} & \multirow{2}{*}{$\begin{array}{l}\text { 3-methyl-6-(1-methylethyl)-2- } \\
\text { cyclohexen-1-one; piperitone }\end{array}$} & \multirow[t]{2}{*}{0.30} \\
\hline 10.768 & eucalyptol & 5.13 & & & \\
\hline 11.123 & hexylene glycol & 0.36 & 21.784 & geranial ( $\alpha^{- \text {citral })}$ & 8.73 \\
\hline 11.736 & \multirow{2}{*}{$\begin{array}{l}\text { 2,6-dimethyl-5-heptenal; bergamal } \\
\gamma^{\text {-terpinene }}\end{array}$} & 0.46 & \multirow[t]{2}{*}{23.794} & \multirow{2}{*}{$\begin{array}{l}\text { methyl 3,7-dimethylocta-2,6-dienoate; } \\
\text { methyl geranate }\end{array}$} & \multirow[t]{2}{*}{2.45} \\
\hline 11.853 & & 0.33 & & & \\
\hline 12.419 & $c^{c i s-}{ }^{- \text {terpineol }}$ & 4.22 & 29.097 & n-decanoic acid; capric acid & 12.44 \\
\hline 12.609 & trans-linaloloxide & 1.99 & 30.202 & isocaryophyllene & 0.65 \\
\hline 13.293 & cis-linaloloxide & 2.81 & 30.530 & methyl 10-methylundecanoate & 1.31 \\
\hline 13.987 & linalool & 5.96 & 30.549 & methyl dodecanoate; methyl laurate & 2.25 \\
\hline \multirow[t]{2}{*}{14.282} & \multirow{2}{*}{$\begin{array}{l}\text { tetrahydro-4-methyl-2-(2-methyl-1- } \\
\text { propenyl)-2H-pyran; rose oxide }\end{array}$} & \multirow[t]{2}{*}{0.14} & 31.464 & caryophyllene oxide & 7.69 \\
\hline & & & 32.695 & dodecanoic acid; lauric acid & 0.29 \\
\hline 14.741 & 3,6-dimethyl-2-octanone & 0.47 & 33.432 & tetradecanoic acid; myristic acid & 0.93 \\
\hline 14.882 & $\alpha^{\text {-campholenal }}$ & 0.52 & 33.842 & 1-heptatriacotanol & 0.08 \\
\hline 15.197 & 2,6-dimethyl-5-heptenol; melonol & 0.14 & 34.474 & 2,10-dimethyl-9-undecenol & 0.64 \\
\hline 15.376 & isopinocarveol & 0.56 & 34.642 & 9-hexadecenoic acid; palmitelaidic acid & 0.17 \\
\hline 15.765 & isopulegol & 0.89 & 34.821 & n-hexadecanoic acid; palmitic acid & 1.56 \\
\hline 16.207 & 3,7-dimethyl-6-octenal; $\beta^{\text {-citronellal }}$ & 2.26 & 35.926 & cis-13-octadecenoic acid & 0.14 \\
\hline 16.334 & $\begin{array}{l}\text { 5-isopropyl-bicyclo[3.1.0]hexan-2- } \\
\text { one; Sabina ketone }\end{array}$ & 0.36 & 36.557 & $\begin{array}{l}1^{\alpha, 3 \alpha, 4},, 6 \alpha^{-4,7,7-t r i m e t h y l-~} \\
\text { bicyclo[4.1.0]heptan-3-ol; 4-caranol }\end{array}$ & 0.12 \\
\hline
\end{tabular}

${ }^{\mathrm{a}}$ Retention indices on a HP-5MS (Agilent 19091S-433, $30 \mathrm{~m} \times 250 \mu \mathrm{m}$ internal diameter, $0.25 \mu \mathrm{m}$ film thickness).

Table 2: Antibacterial activity of the volatile oil and extracts of $L$. cubeba fruits.

\begin{tabular}{lcccccc}
\hline \multirow{2}{*}{ Pathogenic bacteria used } & \multicolumn{7}{c}{ ZOI in $\mathrm{mm}\left(\mathrm{MBC}\right.$ value in $\left.\mu \mathrm{g} \mathrm{mL}^{-1}\right)$} \\
\cline { 2 - 6 } & Litsea oil & $\mathrm{HE}$ & $\mathrm{DE}$ & $\mathrm{EE}$ & $\mathrm{AE}$ & Gentamycin \\
\hline Bacillus subtilis & $17(390.6)$ & $15(195.3)$ & $16(1562.5)$ & - & - & 33 \\
Staphylococcus aureus & $19(6.1)$ & $17(6.1)$ & $17(3125.0)$ & $9(25.0)$ & - & 30 \\
Enterobacter cloacae & $19(48.8)$ & $22(6.1)$ & $12(195.3)$ & $13(3125.0)$ & - & 23 \\
Escherichia coli & $17(0.38)$ & $15(24.4)$ & $15(12500.0)$ & - & - & 23 \\
Klebsiella pneumonia & $19(12.2)$ & $22(48.8)$ & $16(3125.0)$ & - & $11(6250.0)$ & 30 \\
Pseudomonas aeruginosa & $12(12.2)$ & - & - & - & - & 32 \\
Salmonella typhimurium & $17(48.8)$ & $16(195.3)$ & $13(97.6)$ & - & - & 30 \\
Serratia marcescens & $10(195.3)$ & - & - & - & - & 30 \\
\hline
\end{tabular}

Notes: $\mathrm{HE}=$ Hexane extract, $\mathrm{DE}=$ Dichloromethane extract, $\mathrm{EE}=$ Ethyl acetate extract, $\mathrm{AE}=$ Aqueous extract, $(-)$ sign $=$ no ZOI was observed. 
Table 3: Antioxidant activity of the volatile oil and extracts of $L$. cubeba fruits.

\begin{tabular}{|c|c|c|c|}
\hline Samples & $\begin{array}{l}\text { Brine-shrimp lethality } \\
\qquad \mathrm{LC}_{50}\left(\mu \mathrm{g} \mathrm{mL}^{-1}\right)\end{array}$ & $\begin{array}{l}\text { DPPH scavenging activity } \\
\qquad \mathrm{IC}_{50}\left(\mu \mathrm{g} \mathrm{mL}^{-1}\right)\end{array}$ & $\begin{array}{c}\text { DPPH value } \\
\text { (mg GAE } \mathrm{g}^{-1} \text { dried plant material) }\end{array}$ \\
\hline Litsea oil & 31.62 & 1628.85 & Not calculated \\
\hline Hexane extract & 130.31 & 1511.33 & Not calculated \\
\hline Dichloromethane extract & 348.33 & 271.08 & 0.52 \\
\hline Ethyl acetate extract & 21.52 & 124.57 & 0.47 \\
\hline Aqueous extract & 1000.00 & 426.74 & 5.30 \\
\hline Gallic acid & - & 8.56 & - \\
\hline
\end{tabular}

\section{DISCUSSION}

Citral and limonene were reported as major constituents in litsea oil..$^{711,14,18-20,22,23}$ Being citral as major constituent, litsea oil from Nepal constituted neral (7.23\%) and geranial (8.73\%) (Table 1). Other major components present in the oil were capric acid $(12.44 \%)$, caryophyllene oxide (7.69\%), linalool (5.96\%), eucalyptol $(5.13 \%)$, cis- $\beta$-terpineol (4.22\%), 6-methyl-5-hepten-2-one (4.59\%), $\beta$-pinene (3.66\%), p-cymene (3.55\%), etc. Limonene was not detected in the volatile oil. To the best of our knowledge, 3-methyl-2-butenal, hexylene glycol, tetrahydro-4-methyl-2-(2-methyl-1-propenyl)-2H-pyran, 1-(2-methylphenyl)-ethanone, dihydronopol, 1-methyl-2-acetyl3-(1-methylethenyl)-cyclopentane, $\quad 1 \alpha, 3 \alpha, 4 \beta, 6 \alpha-4,7,7$-trimethylbicyclo[4.1.0]heptan-3-ol and 4-caranol were identified for the first time in litsea oil.

Litsea oil showed a higher potentiality for antibacterial activity with ZOI values ranging 10-19 mm and MBC values ranging 0.38-390.6 $\mu \mathrm{g}$ $\mathrm{mL}^{-1}$ for the Gram-positive and Gram-negative bacteria tested (Table 2 ). When we compared the antibacterial activity of litsea oil to that of Chinese variety reported by Wang and Liu, ${ }^{7}$ the oil used in present study was found more effective against $S$. aureus $(\mathrm{MBC}=6.1$ versus $\left.\mathrm{MIC}=200 \mu \mathrm{g} \mathrm{mL}^{-1}\right)$, E. coli $\left(\mathrm{MBC}=0.38\right.$ versus $\left.\mathrm{MIC}=500 \mu \mathrm{g} \mathrm{mL}^{-1}\right)$ and P. aeruginosa $\left(\mathrm{MBC}=12.2\right.$ versus $\left.\mathrm{MIC}=620 \mu \mathrm{g} \mathrm{mL}^{-1}\right)$. The presence of significant amounts of fatty acids and linalool could be responsible for a high antibacterial efficacy of the volatile oil from Nepal. The antibacterial activity of fatty acids and linalool is reported..$^{30,31}$ The hexane and dichloromethane extracts were also found effective except for two strains of bacteria used viz. S. marcescens and $P$. aeruginosa. The ethyl acetate extract showed antibacterial activity against $S$. aureus (ZOI $\left.=9 \mathrm{~mm}, \mathrm{MBC}=25.0 \mu \mathrm{g} \mathrm{mL}^{-1}\right)$ and E. cloacae $(\mathrm{ZOI}=13 \mathrm{~mm}, \mathrm{MBC}=$ $\left.3125.0 \mu \mathrm{g} \mathrm{mL}^{-1}\right)$. The aqueous extract showed poor activity compared to other extracts and could inhibit the growth of $K$. pneumonia $(\mathrm{ZOI}=$ $11 \mathrm{~mm}, \mathrm{MBC}=6250.0 \mu \mathrm{g} \mathrm{mL}^{-1}$ ). The ethyl acetate and aqueous extracts were completely ineffective against $B$. subtilis, E. coli, P. aeruginosa, $S$. typhimurium and $S$. marcescens upon loading of $2.5 \mathrm{mg}$ dose level.

The brine-shrimp assay is reasonably reliable for screening of bioactivity of the plant materials despite inadequate to evaluate the anticancer property. All the isolates exhibited $\mathrm{LC}_{50}=<1000 \mu \mathrm{g} \mathrm{mL}^{-1}$ and therefore were considered pharmacologically active. Litsea oil ( $\mathrm{LC}_{50}$ $\left.=31.62 \mu \mathrm{g} \mathrm{mL}^{-1}\right)$ and the ethyl acetate extract $\left(\mathrm{LC}_{50}=21.52 \mu \mathrm{g} \mathrm{mL}-1\right)$ showed very high cytotoxicity, both hexane $\left(\mathrm{LC}_{50}=130.31 \mu \mathrm{g} \mathrm{mL}^{-1}\right)$ and dichloromethane $\left(\mathrm{LC}_{50}=348.33 \mu \mathrm{g} \mathrm{mL}^{-1}\right.$ ) extracts were moderately cytotoxic, and the aqueous extract has displayed marginal cytotoxicity $\left(\mathrm{LC}_{50}=1000.00 \mu \mathrm{g} \mathrm{mL}^{-1}\right)$. Recently, we ${ }^{32}$ and another group ${ }^{33}$ have reported the brine-shrimp lethality assay of litsea oil.

To the best of our knowledge, DPPH free radical scavenging activity of $L$. cubeba is rarely investigated. ${ }^{9,34}$ The ethyl acetate and dichloromethane extracts displayed a modest antioxidant activity with $\mathrm{IC}_{50}$ values of 124.57 and $271.08 \mu \mathrm{g} \mathrm{mL} \mathrm{m}^{-1}$, respectively (Table $3)$. The aqueous extract exhibited a weak antioxidant activity $\left(\mathrm{IC}_{50}\right.$ $\left.=426.74 \mu \mathrm{g} \mathrm{mL}^{-1}\right)$. Although litsea oil and the hexane extract were cytotoxic against brine-shrimp nauplii; however, they were poor in scavenging of DPPH free radical. The aqueous extract possesses a high quantity of antioxidants as GAE due to its higher extractive value (for dichloromethane extract $=0.55 \%$, ethyl acetate extract $=0.33 \%$ and aqueous extract $=11.72 \%$ ).

\section{CONCLUSION}

In conclusion, litsea oil of L. cubeba fruits from Nepal was analyzed by GC-MS and forty-nine components were identified. Besides citral; capric acid, caryophyllene oxide, linalool, eucalyptol, cis- $\beta$-terpineol, 6 -methyl-5-hepten-2-one, $\beta$-pinene, $p$-cymene, etc. were abundantly deposited in the oil showing genuineness of the product. Litsea oil and other extracts (particularly hexane and dichloromethane extracts) displayed a high antibacterial activity. The study of brine-shrimp and DPPH assays of the oil and extracts indicated that the plant material constituted of potential anticarcinogenic agents.

\section{ACKNOWLEDGEMENT}

We thank Nepal Academy of Science and Technology (NAST) for all the supports to carry out this work.

\section{CONFLICTS OF INTEREST}

The authors declare no conflicts of interest.

\section{ABBREVIATIONS}

DPPH: 2,2-diphenyl-1-picrylhydrazyl; GC-MS: gas chromatographymass spectrometry; $\mathrm{IC}_{50}: 50 \%$ inhibition concentration; $\mathrm{LC}_{50}$ : lethal concentration for $50 \%$ mortality; MBC: minimum bactericidal concentration; MIC: minimum inhibitory concentration; ZOI: zone of inhibition.

\section{REFERENCES}

1. Gurung K. Essential oils in Nepal: a practical guide to essential oils and aromatherapy. Himalayan Bio Trade Pvt. Ltd.: Kathmandu, Nepal; 2009.

2. Agrawal N, Choudhary AS, Sharma MC, Dobhal MP. Chemical constituents of plants from the genus Litsea. Chem. Biodiversity. 2011;8:223-43.

3. Caja MM, Preston C, Kempf M, Schreier P. Flavor authentication studies of $\alpha$-lonone, $\beta$-lonone and $\alpha$-lonol from various sources. J Agric Food Chem. 2007;55:6700-4

4. Jiang Z, Akhtar $Y$, Bradbury $R$, Zhang $X$, Isman MB. Comparative toxicity of essential oils of Litsea pungens and Litsea cubeba and blends of their major constituents against the cabbage looper, Trichoplusia ni. J Agric Food Chem. 2009:57:4833-7.

5. Mercier C, Chabarde P. Organometallic chemistry in industrial vitamin A and vitamin E synthesis. Pure Appl Chem. 1994;66:1509-18.

6. Feng $T, X u Y$, Cai $X H, D u Z Z, L u o X D$. Antimicrobially active isoquinolinone alkaloids from Litsea cubeba. Planta Medica. 2009;75:76-9.

7. Wang $\mathrm{H}$, Liu Y. Chemical composition and antibacterial activity of essential oils from different parts of Litsea cubeba. Chem Biodiversity. 2010;7:229-35.

8. Yang $Y$, Jiang J, Qimei L, Yan $X$, Zhao J, Yuan $\mathrm{H}$, et al. The fungicidal terpenoids and essential oil from Litsea cubeba in Tibet. Molecules. 2010;15:7075-82.

9. Hwang JK, Choi EM, Lee JH. Antioxidant activity of Litsea cubeba. Fitoterapia 2005;76:684-6.

10. Noosidum A, Prabaripai A, Chareonviriyaphap T, Chandrapatya A. Excitorepellency properties of essential oils from Melaleuca leucadendron L., Litsea cubeba (Lour.) Persoon and Litsea salicifolia (Nees) on Aedes aegypti (L.) mosquitoes. J Vector Ecol. 2008;33:305-12. 
11. Ho CL, Jie-Pinge O, Liu YC, Hung CP, Tsai MC, Liao PC, et al. Compositions and in vitro anticancer activities of the leaf and fruit oils of Litsea cubeba from Taiwan. Nat Prod Commun. 2010;5:617-20.

12. Lawrence BM. Progress in essential oils. Perfumer Flavorist. 1993;18:53-61.

13. Yipei B. Progress and status of research on Chinese Litsea cubeba oil. Chem Ind Forest Prod. 1995;15:71-7.

14. Hu L, Wang Y, Du M, Zhang J. Characterization of the volatiles and active components in ethanol extracts of fruits of Litsea cubeba (Lour.) by gas chromatography-mass spectrometry (GC-MS) and gas chromatographyolfactometry (GC-O). J Med Plants Res. 2011;5:3298-303.

15. Si L, Chen Y, Han X, Zhan Z, Tian S, Cui Q, et al. Chemical composition of essential oils of Litsea cubeba harvested from its distribution areas in China. Molecules. 2012; 17:7057-66.

16. Zhan YS, Long YC, Ye FN, Zhou JH. Studies on the analysis of Litsea cubeba oil in human by gas chromatography. Chinese J Chromatog. 1985;2:190-4.

17. Zhou YH, Wang LS, Liu XM. GC-MS analysis of Litsea cubeba oil obtained in GuangXi. J Chem Ind Forest Prod. 2003;37:19-21.

18. Gogoi P, Baruah P, Nath SC. Antifungal activity of the essential oil of Litsea cubeba Pers. J Essent Oil Res. 1997;9:213-5

19. Ko K, Juntarajumnong W, Chandrapatya A. Repellancy, fumigant and contact toxicities of Litsea cubeba (Lour.) Persoon against Sitophilus zeamais Motschulsky and Tribolium castaneum (Herbst). Kasetsart J Nat Sci. 2009; $43: 56-63$

20. Park IK, Kim J, Lee SG, Shin SC. Nematicidal activity of plant essential oils and components from ajowan (Trachyspermum ammi), allspice (Pimenta dioica) and litsea (Litsea cubeba) essential oil against pine wood nematode (Bursaphelenchus xylophilus). J Nematology. 2007;39:275-9.

21. Su YC, Ho CL. Essential oil compositions and antimicrobial activities of various parts of Litsea cubeba from Taiwan. Nat Prod Commun. 2016;11:515-8.

22. Choudhury S, Ahmed R, Barthel A, Leclercq PA. Composition of the stem, flower and fruit oils of Litsea cubeba Pers. from two locations of Assam, India. J Essent Oil Res. 1998;10:381-6.
23. Wang Y, Jiang ZT, Li R. Antioxidant activity, free radical scavenging potential and chemical composition of Litsea cubeba essential oil. J Essent.Oil Bearing Plants. 2012;15:134-43.

24. Ciulei I. Methods for studying vegetables drugs. Chemical Industries Branch Division of Industrial Operations, UNIDO: Bucharest, Romania; 1982.

25. Harborne JB. Phytochemical methods: a guide to modern techniques of plant analysis. 2nd ed. Chapman and Hall Ltd.: New York; 1973

26. Dingle J, Reid WW, Solomons GL. The enzymic degradation of pectin and other polysaccharides. II - application of the 'cup-plate' assay to the estimation of enzymes. J Sci Food Agric. 1953;4:149-55.

27. Clinical and Laboratory Standards Institute. Methods for dilution antimicrobia susceptibility tests for bacteria that grow aerobically; approved standard. CLSI document M7-A7. $7^{\text {th }}$ ed. Wayne, Pennsylvania: USA; 2006.

28. Meyer BN, Ferrigni NR, Putnam JE, Jacobsen LB, Nichols DE, McLaughlin $\mathrm{JL}$. Brine shrimp: a convenient general bioassay for active plant constituents. Planta Medica, 1982;45:31-4

29. Brand-Williams W, Cuvelier ME, Berset C. Use of a free radical method to evaluate antioxidant activity. LWT - Food Sci Technol. 1995;28:25-30

30. Desbois AP, Smith VJ. Antibacterial free fatty acids: activities, mechanisms of action and biotechnological potential. Appl. Microbiol. Biotechnol. 2010;85:1629 42.

31. Nguyen HV, Caruso D, Lebrun M, Nguyen NT, Trinh TT, Meile JC, et al Antibacterial activity of Litsea cubeba (Lauraceae, May Chang) and its effects on the biological response of common carp Cyprinus carpio challenged with Aeromonas hydrophila. J Appl Microbiol. 2016;121:341-51.

32. Bajracharya GB, Tuladhar SM. Brine-shrimp bioassay for assessment of anticancer property of essential oils from spices. Nepal J Sci Technol. 2011;12:163-70.

33. Abdul HS, Ahmad F. Chemotype of Litsea cubeba essential oil and its bioactivity Nat Prod Commun. 2015;10:1301-4

34. Li F, Zhang M, Holness H, O'Shea K. Effects of different solvent extract and fractions from Litsea cubeba on antioxidant activity and its GC-MS analysis. $J$ Xuzhou Inst Technol Nat Sci Ed. 2013:28:28-32.

\section{GRAPHICAL ABSTRACT}

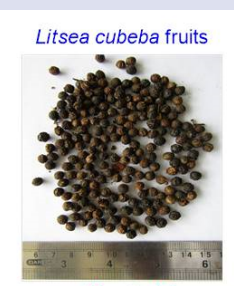

antibacterial, antibacterial,
cytotoxic, antioxidative caryophyllene oxide

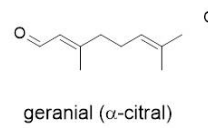

$\mathrm{N}^{\mathrm{O}}$

neral ( $\beta$-citral)<smiles>C=C1CCC2(O)OC2CCC1C(C)(C)C</smiles>

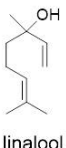

HO

capric acid

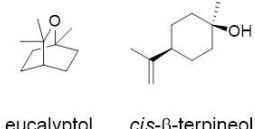

\section{SUMMARY}

- This work showed litesa oil from the fruits of Litsea cubeba (Lour.) Pers from Nepal abundantly constituted citral, capric acid, caryophyllene oxide, linalool, eucalyptol, cis- $\beta$ terpineol, etc.

- Litsea oil and the fruits extracts have displayed high antibacterial and potentially anticarcinogenic activities using antibacterial susceptibility, brine-shrimp lethality and DPPH assays.

\section{ABOUT AUTHORS}

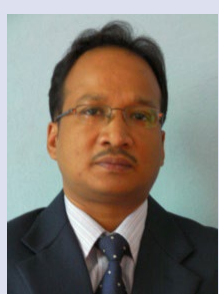

Dr. Gan B. Bajracharya is a Senior Scientific Officer at Nepal Academy of Science and Technology, Nepal. He received his Doctor of Science degree in 2004 from Tohoku University, Japan working under Prof. Yoshinori Yamamoto. He carried out post-doctoral researches at Osaka University, Japan; University of Houston, Texas; and HEJ Research Institute of Chemistry, University of Karachi, Pakistan. He has published about 50 research articles in international and national peer-reviewed journals. His research interest is focused on the development of catalytic reactions and natural product chemistry.

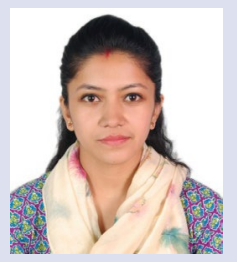

Ms. Pratigya KC obtained Maters degree in chemistry from Tri-Chandra Multiple Campus, Tribhuvan University, Nepal in 2014. She is currently working as a Lecturer of engineering chemistry at Himalaya College of Engineering, Lalitpur, Nepal.

Cite this article: Bajracharya GB, Pratigya KC. A High Antibacterial Efficacy of Fruits of Litsea cubeba (Lour.) Pers from Nepal. GCMS and Antioxidative Capacity Analyses. Pharmacog J. 2019;11(5):889-93. 